\title{
Morphofunctional Lab as a Learning Scenario of Apprenticeship in Universidade Do Planalto Catarinense (UNIPLAC) Medical Course
}

\author{
Patricia Alves de Souza, Adriane Marcia Andrade, Fernando Arruda Ramos, \\ Rafael Sittoni Vaz \\ Universidade do Planalto Catarinense (UNIPLAC), Gepes Vida Research Group, Lages, Brazil \\ Email: propepg@uniplaclages.edu.br
}

Received 16 February 2014; revised 16 March 2014; accepted 23 March 2014

Copyright (C) 2014 by authors and Scientific Research Publishing Inc.

This work is licensed under the Creative Commons Attribution International License (CC BY).

http://creativecommons.org/licenses/by/4.0/

(c) (i) Open Access

\section{Abstract}

In Brazil, the National Curricular Guidelines (DCN) have determined that the medical professsional must act in the primary and secondary levels of attention and solve the prevalent health issues with quality. UNIPLAC's medical course was created in 2004, enrolling 40 students per year, with an innovative methodological proposal of active teaching: the Problem-Based Learning (ABP). Furthermore, UNIPLAC's medical course offers support scenarios of extreme importance to the students, such as Laboratory of Professional Practice (LPP) and Morphofunctional Laboratory (LMF). LPP promotes the learning of semiology skills, medical procedures, clinical laboratory and communication. The objective is to identify the student's attendance in LMF. A quantitative and descriptive research was conducted through reading the LMF's logbook between January 2004 and December 2012. The focus of the research was tutors and teachers who were in the coordination of the medical course. LMF is a privileged space for the development of the pedagogical approach based on problematization and integration of a several learning areas.

\section{Keywords}

Learning Scenario; Medical Course 


\section{Introduction}

In Brazil, the National Curricular Guidelines (DCN) have determined that the medical professional must act in the primary and secondary levels of attention and solve the prevalent health issues with quality. DCN comprise a set of doctrinal definitions regarding principles, foundations and procedures during training, guiding the courses in the organization, articulation, development and evaluation of their pedagogic proposals. DCN promote a general, humanist, critical, and reflexive training. Through ethical principles, the guidelines enable professionals for promoting integral health of the human being, as well as they are able for working on a team (Brasil, 2001). DCN also foresee that the teaching-learning process is essential for developing the practice of health assistance.

Thus, the medical course focuses teachings on basic care, targeting Brazilian Public Health in 100\% of courses, just as graduate studies target basic care in large areas, allowing the development of research and permanent education of health professionals (Souza, Zeferino, \& Da Ros, 2011).

Students conduct the activities on the Single Health System (SUS-free health care system for the Brazilian population), at the same time contributing to the enhancement and strengthening of the basic care network (health units), families and communities (Costa, 2010).

Universidade do Planalto Catarinense (UNIPLAC) was founded in 1953 and the medical course was created in 2004, enrolling 40 students per year, with an innovative methodological proposal of active teaching: the Problem-Based Learning (ABP).

By the entrance of LMF, there is a table with a logbook for each of the years of the training, in which students should register their signature and the subject they are researching there. The objective is to identify the student's attendance in LMF.

\section{Methodology}

A quantitative, descriptive research was conducted, through the reading of LMF's logbook between January 2004 and December 2012. As leituras e tabulações dos dados foram realizadas no Excel 2007. The coordination of the medical course informou sobre todos survey of the tutors and teachers que trabalharam no LMF orientando os alunos, esses dados foram tabulados no Excel 2007.

\section{Results}

The data registered in the logbooks was surveyed. Unfortunately, often students do not fill the subject they will study during the LMF.

Table 1 shows the attendance of students in the Morphofunctional laboratory per current year and per course year.

Most of the attendance of LMF consists of first and second year students. From the fourth year forward, students tend to increase the number of activities performed outside the institution where LMF is located (Figure 1).

In addition to LMF and LPP, there are other important learning scenarios, such as the Basic Health Units (fully free treatment for the population) in which the students are included since the first year.

At all times, a close relationship between actual practice and the content learned in theory is aimed, without prioritizing the classroom, as it was done in the traditional model (Cotta, 2007).

As LMF is not a mandatory scenario, it allows spontaneous demand from the student. Being it this way, learning becomes a creative adventure for the student, which makes it a much richer experience than simple repetition of lessons.

In this context, the student manages their own time, acquiring responsibility for his/her development and autodidact learning, for which LMF offers indispensable and innovative resources for knowledge searching.

LMF's tutors are voluntary students. From 2004 to 2012, the total number of tutors was of 73, being 44 men and 29 women (Figure 2). It has been identified that only 3 were not enrolled in the medical course, being one of those from Dentistry Course and two from Nursing Course (tutors during 2004 and 2006), due to the early stage in which the Medical Course found itself. After 2006, only medical students were responsible for tutoring programs in LMF.

\section{Discussion}

ABP allows students the responsibility of building their knowledge through problems that seek to simulate real- 
P. A. de Souza et al.

Table 1. Student's attendance in LMF per year, in comparison to current year.

\begin{tabular}{|c|c|c|c|c|c|c|c|c|c|}
\hline & $\begin{array}{l}\text { Year } \\
2004\end{array}$ & $\begin{array}{l}\text { Year } \\
2005\end{array}$ & $\begin{array}{l}\text { Year } \\
2006\end{array}$ & $\begin{array}{l}\text { Year } \\
2007\end{array}$ & $\begin{array}{l}\text { Year } \\
2008\end{array}$ & $\begin{array}{l}\text { Year } \\
2009\end{array}$ & $\begin{array}{l}\text { Year } \\
2010\end{array}$ & $\begin{array}{l}\text { Year } \\
2011\end{array}$ & $\begin{array}{l}\text { Year } \\
2012\end{array}$ \\
\hline $1^{\text {st }}$ Year & 701 & 787 & 1174 & 1549 & 1205 & 1835 & 747 & 1289 & 1465 \\
\hline $2^{\text {nd }}$ Year & $\mathrm{X}$ & 374 & 908 & 873 & 899 & 653 & 894 & 765 & 389 \\
\hline $3^{\text {rd }}$ Year & $\mathrm{X}$ & $\mathrm{X}$ & 534 & 596 & 282 & 447 & 342 & 521 & 249 \\
\hline $4^{\text {th }}$ Year & $\mathrm{X}$ & $\mathrm{X}$ & $X$ & 193 & 222 & 298 & 411 & 182 & 226 \\
\hline $5^{\text {th }}$ Year & $\mathrm{X}$ & $\mathrm{X}$ & $\mathrm{X}$ & $X$ & 43 & 35 & 83 & 79 & 103 \\
\hline $6^{\text {th }}$ Year & $X$ & $X$ & $X$ & $X$ & $\mathrm{X}$ & 65 & 74 & 118 & 49 \\
\hline
\end{tabular}

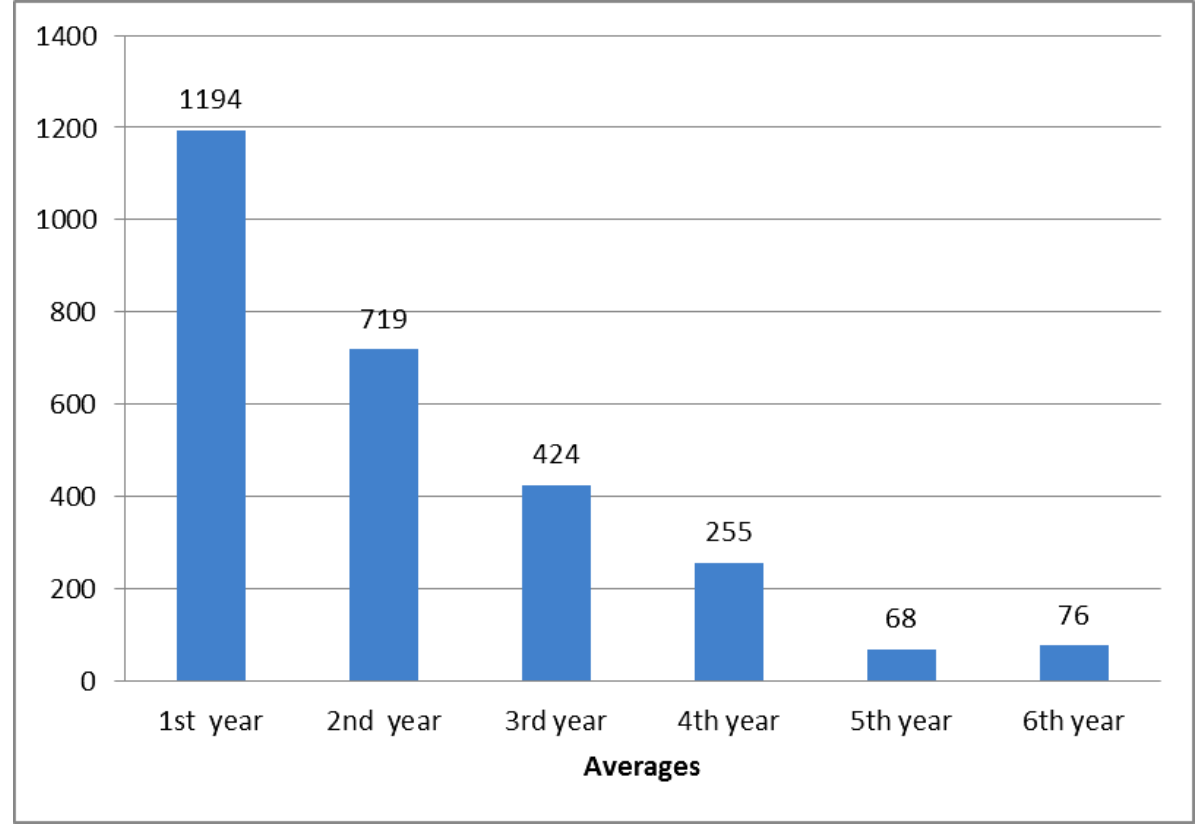

Figure 1. Average of medical course students attendance in LMF, per year.

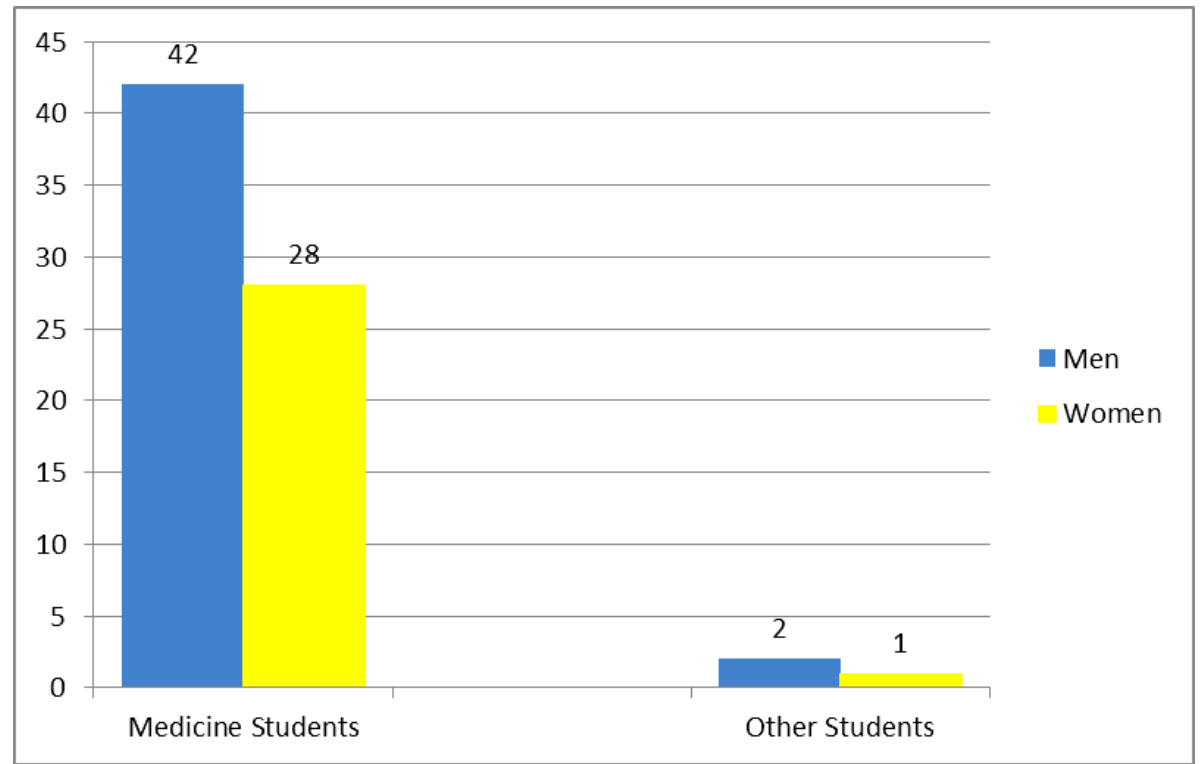

Figure 2. Number of tutors divided by sex and by course since LMF’s foundation (2004). 
ity closely, enabling the direct contact with patients since the beginning of the course, teaching them how to deal with the challenges of Medical Courses and to relate theoretical contents with reality (UNIPLAC, 2013).

Since its conception, UNIPLAC's medical course highlights the need for working with active methodologies of teaching and learning at its core, privileging the use of ABP in the Systemized Educational Unities and the Problematization in the Educational Unities of Health Practice in the Community and Internship Educational Unity. Among individual standards of learning, these methodologies take into consideration characteristics such as the relationship of each student with the location, time, attendance and schoolmates, the way in which they take personal notes, the way of setting individual goals to be achieved, the reading skill, the critical thought, the analysis and synthesis, the decision about what, where and how to study, the profile of application of the diversity of sources and resources of learning, the self-motivation, and the capacity for self-evaluation (UNIPLAC, 2003).

Furthermore, UNIPLAC's medical course offers support scenarios of extreme importance to the students, such as Laboratory of Professional Practice (LPP) and Morphofunctional Laboratory (LMF). LPP promotes the learning of semiology skills, medical procedures, clinical laboratory and communication (UNIPLAC, 2003).

LMF integrates educational resources from specializations such as: anatomy, histology, physiology, immunology, pathology and other areas prepared in accordance with the development of educational unities. It applies molds, posters, panels, microscopes and blades, videotapes, slabs, specimens, pieces, slides, CDs and DVDs, computers with access to virtual libraries and bibliographical support for research. LMF is divided by areas of knowledge: cellular growth and differentiation, mobility, skin and soft parts, attack and defense, nervous system, cardiovascular system, respiratory system, digestive system, endocrine system, urinary system, hematological system, cycle of life and reproduction, and collective health (UNIPLAC, 2013). LMF is not a mandatory scenario.

This laboratory is also used by students for their pro study time, in which they improve their skills of "learning and knowing how to think" (UNIPLAC, 2003).

It is a lab of teaching-learning, used in individual activities or in small groups, self-directed, supervised by instructors (teachers) and tutors (students), always integrating theoretical and practical knowledge essential to each unity and to professional practice. The educational unities may schedule specific activities in the laboratory, always in accordance with planned learning objectives (UNIPLAC, 2013). Complementary activities seek the constitution of integration spaces when used as training practices (Garcia, 2007).

Thus, to learn is to build, rebuild, analyze to intervene and change in order to, in this "voyage" of learning, allow the student to become a critic subject, who constructs knowledge based on the problematization of the object and on being a part of this process (Freire, 1999).

\section{Conclusion}

Most students in attendance of LMF are from the first two years of the course. Most tutors are from the medical course. DCN suggests the inclusion of the student, since the very beginning, in diversified scenarios of teaching-learning, and emphasizes the role played by basic attention on this process. It is understood that the establishment of new practice scenarios, the valorization of the psychosocial and anthropological dimensions of illnesses and the incorporation of relational technologies during the medical training enable the refocusing on the subjective aspects of illnesses and also allow a widened comprehension of the health-disease process (Nogueira, 2009).

LMF is a privileged space for the development of the pedagogical approach based on problematization and integration of a several learning areas.

The establishment of new practice scenarios during medical training enables the refocusing on the subjective aspects of illnesses, granting more visibility to the social, cultural and psychological matters of the diseased patient, in a widened comprehension of the health-disease process. Therefore, due to these new scenarios, new situations are experienced in the clinical practice and production of attention to health (Nogueira, 2009).

LMF is a learning scenario, where students are given a role in the teaching-learning process, which offers a change of emphasis in contents towards an active and independent learning process, enabling the overcoming of the dichotomy between theory and practice, enhancing works articulated with the health services and populations (Stella, 2009).

The main incentive for such extracurricular activities is the improvement of the clinical practice, as well as 
the upgrading of the students' curriculum. It is impossible to know exactly if the students who are participating in these activities in LMF had a better performance during the training modules.

Current medical training literature recognizes the relevance of extracurricular activities in the development of medical students, which opens up the possibility of the integration of such activities in the regular curriculum (Tavares, 2007). This creates, in a sense, a self-taught physician.

\section{References}

Brasil. Ministério da Educação (2001). Parecer CNE/CES n. 1133 de 07 de agosto de 2001. Diretrizes curriculares nacionais dos cursos de graduação em enfermagem, medicina e nutrição. Brasília.

Costa, E. M. A., \& Carbone, M. H. (2010). Saúde da família: uma abordagem multidisciplinar. Rio de janeiro.

Cotta, E. M. M., Gomes, A. P., Maia, T., Magalhaes, K. A., Marques, E. S., \& Siqueira, B. (2007). Injustiça e desigualdade social: repensando a formação de profissionais de saúde. Revista Brasileira de educação Médica, 3, 278-286. http://dx.doi.org/10.1590/S0100-55022007000300010

Freire, P. (1999). Pedagogia da autonomia: saberes necessários à prática educativa (11 ${ }^{\mathrm{a}}$ ed.). Rio de janeiro: Paz e terra.

Garcia, M. A. A., Pinto, A. T. B. C. S., Odoni, A. P. C., Longhi, B. S., Machado, L. I., Linek, M. D. S., \& Costa, N. A. (2007). A Interdisciplinaridade Necessária à educação Médica. Revista Brasileira de educação Médica, 31, 147-155. http://dx.doi.org/10.1590/S0100-55022007000200005

Nogueira, M. I. (2009). As Mudanças na Educação Médica Brasileira em Perspectiva: Reflexão sobre a emergência de um novo estilo de pensamentos. Revista Brasileira de educação Médica, 33, 262-270. http://dx.doi.org/10.1590/S0100-55022009000200014

Souza, P. A., Zeferino, A. M. B., \& Ros, M. A. D. (2011). Currículo integrado: entre o discurso e a prática. Revista Brasileira de educação Médica, 35, 20-25. http://dx.doi.org/10.1590/S0100-55022011000100004

Stella, R. C. R., Abdalla, I. G., Lampert, J. B., Perim, G. L., Silva, R. H., \& Costa, N. M. C. (2009). Cenário de práticas e a formação Médica na assistência em Saúde. Revista brasileira de educação Médica, 22, 63-69. http://dx.doi.org/10.1590/S0100-55022009000500007

Tavares, A. P., Ferreira, R. A., França, E. B., Fonseca, C. A. J., Lopes, G. C., Dantas, N. G. T., \& Cardoso, S. A. V. (2007). O currículo paralelo dos estudantes de Medicina da Universidade Federal de Minas Gerais. Revista Brasileira de educação Médica, 31, 254-265.

UNIPLAC (2003). Universidade do Planalto Catarinense. Projeto do Curso de graduação em Medicina da UNIPLAC. http://www.uniplac.net/

UNIPLAC (2009). Universidade do planalto Catarinense. Caderno do Estudante do Curso de Medicina. http://www.uniplac.net/ 